\title{
Correction to: Targeted provider education and pre-visit planning increase rates of formal depression screening in childhood- onset SLE
}

Evan Mulvihill ${ }^{1,5,6^{*}}$, Rebecca Furru ${ }^{2}$, Alana Goldstein-Leever ${ }^{3}$, Kyla Driest $^{1}$, Stephanie Lemle ${ }^{4}$, Darby MacDonald ${ }^{1}$, Emily Frost ${ }^{1}$ and Vidya Sivaraman ${ }^{1}$

\section{Correction to: Pediatr Rheumatol 19, 116 (2021) https://doi.org/10.1186/s12969-021-00576-4}

Following publication of the original article [1], the authors identified an error in the author name of Alana Goldstein-Leever.

- The incorrect author name is: Alanna Goldstein-Leever

- The correct author name is: Alana Goldstein-Leever

The author group has been updated above and the original article [1] has been corrected.

\footnotetext{
Author details

'Department of Pediatrics, Divisions of a Rheumatology, Nationwide Children's Hospital and The Ohio State University, Columbus, OH, USA. ${ }^{2}$ Department of Social Work, Nationwide Children's Hospital, The Ohio State University, Columbus, OH, USA. ${ }^{3}$ Department of Pediatric Psychology and Neuropsychology, Nationwide Children's Hospital and The Ohio State University, Columbus, OH, USA. ${ }^{4}$ Department of QI Services, Nationwide Children's Hospital and The Ohio State University, Columbus, OH, USA. ${ }^{5}$ Department of Pediatrics, Division of Rheumatology, Nemours/A.I. duPont Hospital for Children, and Thomas Jefferson University, Wilmington, DE, USA. ${ }^{6}$ Department of Pediatrics, Division of Rheumatology, Nemours Hospital for Children Division of Rheumatology, 1600 Rockland Road, Wilmington, DE 19803, USA.
}

Published online: 23 August 2021

\section{Reference}

1. Mulvihill E, Furru R, Goldstein-Leever A, Driest K, Lemle S, MacDonald D, et al. Targeted provider education and pre-visit planning increase rates of formal depression screening in childhood-onset SLE. Pediatr Rheumatol. 2021). https://doi.org/10.1186/s12969-021-00576-4;19(1):116.

The original article can be found online at https://doi.org/10.1186/s12969021-00576-4.

* Correspondence: evan.mulvihill@nemours.org

'Department of Pediatrics, Divisions of a Rheumatology, Nationwide

Children's Hospital and The Ohio State University, Columbus, OH, USA

${ }^{5}$ Department of Pediatrics, Division of Rheumatology, Nemours/A.I. duPont

Hospital for Children, and Thomas Jefferson University, Wilmington, DE, USA

(c) The Author(s). 2021 Open Access This article is licensed under a Creative Commons Attribution 4.0 International License, which permits use, sharing, adaptation, distribution and reproduction in any medium or format, as long as you give appropriate credit to the original author(s) and the source, provide a link to the Creative Commons licence, and indicate if changes were made. The images or other third party material in this article are included in the article's Creative Commons licence, unless indicated otherwise in a credit line to the material. If material is not included in the article's Creative Commons licence and your intended use is not permitted by statutory regulation or exceeds the permitted use, you will need to obtain permission directly from the copyright holder. To view a copy of this licence, visit http://creativecommons.org/licenses/by/4.0/ The Creative Commons Public Domain Dedication waiver (http://creativecommons.org/publicdomain/zero/1.0/) applies to the data made available in this article, unless otherwise stated in a credit line to the data. 